\title{
PIPER (PIPERACEAE) IN THE PHILIPPINE ISLANDS: THE CLIMBING SPECIES
}

\author{
RHYS O. GARDNER \\ Auckland War Memorial Museum, Private Bag 92018, Auckland, New Zealand
}

\begin{abstract}
SUMMARY
Piper in the Philippine Islands is reviewed. Fifteen climbing species are recognized (many fewer than in previous treatments) and distinguished in a key. Most are widely distributed through Malesia, with ranges that end eastwards in the Solomon Islands or Australia. Piper myrmecophilum, the only taxon accepted as endemic to the Philippines, is ant-associated. Piper celtidiforme, once thought endemic, also occurs in New Guinea and the Solomons.

The five shrubby Piper species in the Philippines are briefly described.
\end{abstract}

Key words: Piper, Philippine Islands, taxonomy.

\section{INTRODUCTION}

For the Philippine Islands C. de Candolle (1910, 1923) and then Merrill (1923) recognized more than a hundred native species of Piper, nearly all of them climbers. This tradition was continued by Quisumbing (1930), in a monograph that treated eighty-three native climbing species and a number of varieties. Exemplary though Quisumbing's work is in its detailed descriptions, copious illustration and comprehensive examination of specimens, it seems to me to be based on an unrealistically narrow species concept. It compares unfavourably, for example, with the compact account of Piper in Java (Backer \& Bakhuizen van den Brink, 1963), in which only eighteen native climbing species are recognized. I would also point to the numerous reductions effected by Chew $(1972,1992,2003)$ for Piper elsewhere in Malesia, many of which involve De Candollean names.

The treatment offered here reduces the number of wild Philippine climbing species to fifteen. Of these, only P. myrmecophilum C.DC. is endemic, the others mostly being widespread in Malesia, in some cases ranging west to India or south-east to the Solomon Islands or Australia.

The names used here for these fifteen species all feature in Quisumbing's (1930) revision, with two exceptions. The first, $P$. macropiper Pennant, is an earlier name for P. arborescens Roxb. (Merrill, 1948). With respect to the second, P. quinqueangulatum Miq., I follow Backer \& Bakhuizen van den Brink (1963: 170) who indicate it to be an earlier name for $P$. korthalsii Miq.

Types of the fifteen accepted taxa, and of the numerous taxa considered likely to be synonyms, have mostly not been examined by me. (But photographs of the holotypes of $P$. abbreviatum, $P$. celtidiforme and P. interruptum are to be found in Quisumbing 


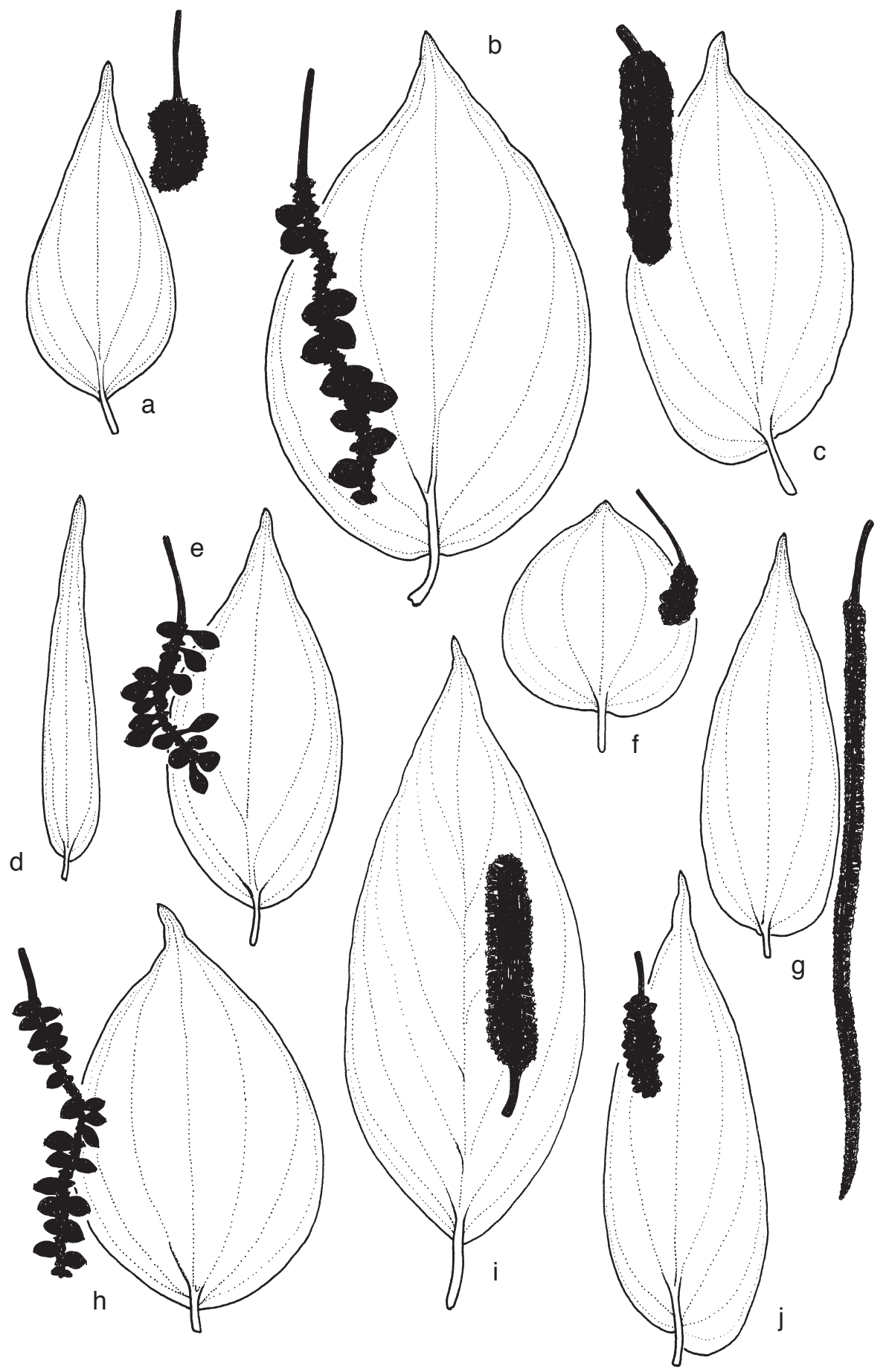


(1930).) For this reason, and to avoid premature nomenclatural changes pending further study on Piper in Indo-Malesia, likely synonyms are mentioned only in passing.

The key below should allow the great majority of Philippine climbing pipers to be determined (fertile ones, at least). If it fails it may be that the specimen actually represents one of the five non-climbing species - see the section 'Shrubby Species' after the list of the climbing species, and also the descriptions of Quisumbing (1930), Backer \& Bakhuizen van den Brink (1963) and Gardner (2003).

\section{METHODS}

This study is based on an examination of specimens from AK, BISH, BRIT, CANB, MEL, and on live material seen in New Guinea between 1993 and 2000. The descriptions and measurements derive mostly from the dry specimens. Notes on extra-Philippines distribution and typification have mostly been taken from Quisumbing (1930) and Chew $(1972,2003)$.

\section{CHARACTERS}

\section{Vegetative parts}

Like most shrubby Malesian pipers the climbing species too have dimorphic foliage. The leaves of their orthotropic 'climbing' shoots have a sheathing petiole, while those of the fertile plagiotropic shoots, which are tipped by a convolute prophyll or 'stipule', have non-sheathing petioles (Gardner, 2003). The species tend to resemble one another relatively strongly in their climbing-shoot leaves, which are broader and more strongly cordate than those of the fertile shoots. This can make it difficult to identify juvenile and sterile foliage. The exception is $P$. fragile, whose climbing-shoot leaves can be peltate.

Leaf shape on the fertile shoots varies considerably but the degree to which the nerves are palmately or pinnately arranged is relatively constant (Fig. 1-3). Unfortunately for descriptive purposes, outside the principal nerves there are always weaker ones that form looping (sub)marginal veins for some distance. Therefore, descriptions of the number of basal nerves can vary from author to author. In what follows the outermost nerves are not counted if they are too weak to be seen by the naked eye at normal reading distance.

Most of the species have a slight to moderate amount of indument on their vegetative parts. Usually the hairs are pale and less than a millimetre long (e.g., P. caninum, $P$. lessertianum). Sometimes they are longer (3 mm long in $P$. myrmecophilum), bristly

Fig. 1. Piper species. Fertile-shoot leaves $(\mathrm{a}-\mathrm{c}, \mathrm{e}-\mathrm{j} \times 0.5 ; \mathrm{d} \times 1)$ and infructescences $($ generalized $\times 1)$. - a. P. abbreviatum Opiz; after Quisumbing (1930), f. 24. - b. P. baccatum Blume; after Quisumbing (1930), f. 96. - c. P. betle L.; after Quisumbing (1930), f. 41. - d. P. caninum Blume; after Quisumbing (1930), f. 66, as P. viminale. - e. P. caninum Blume; after Quisumbing (1930), f. 62. - f. P. fragile Benth.; after Quisumbing (1930), f. 50. - g. P. macropiper Pennant; after Quisumbing (1930), f. 2. - h. P. interruptum Opiz; after Quisumbing (1930), f. 85. - i. P. celtidiforme Opiz; after Quisumbing (1930), f. 102, as P. villirache.-j. P. lessertianum (Miq.) C.DC.; after Quisumbing (1930), f. 10. 


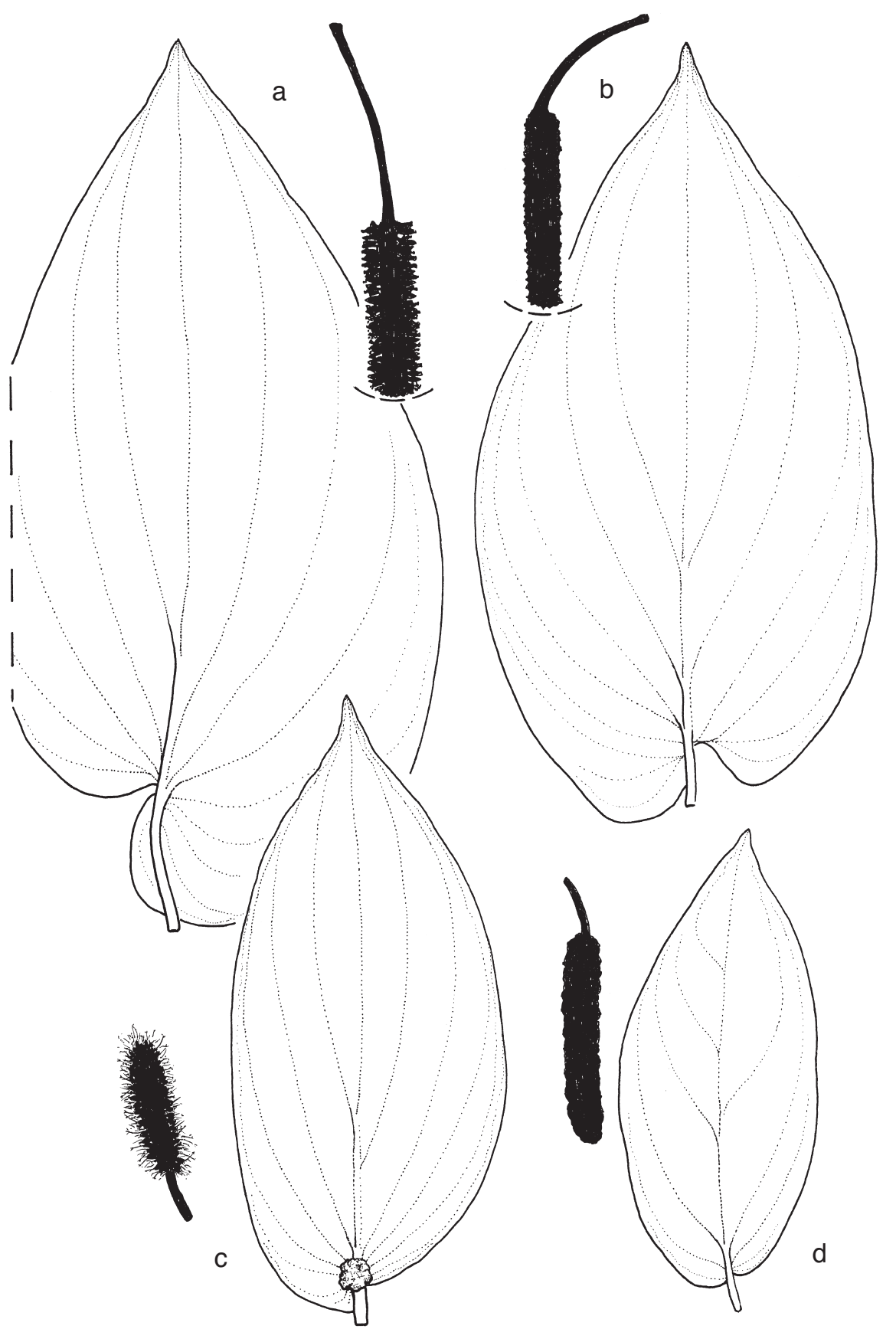

Fig. 2. Piper species. Fertile-shoot leaves $(\times 0.5)$ and infructescences (generalized $\times 1) .-$ a. P. decumanum L.; after Quisumbing (1930), f. 14; spike greatly truncated. - b. P. majusculum Blume; after Quisumbing (1930), f. 16; spike greatly truncated. - c. P. myrmecophilum C.DC.; after Quisumbing (1930), f. 23. - d. P. retrofractum Vahl; after Quisumbing (1930), f. 54. 

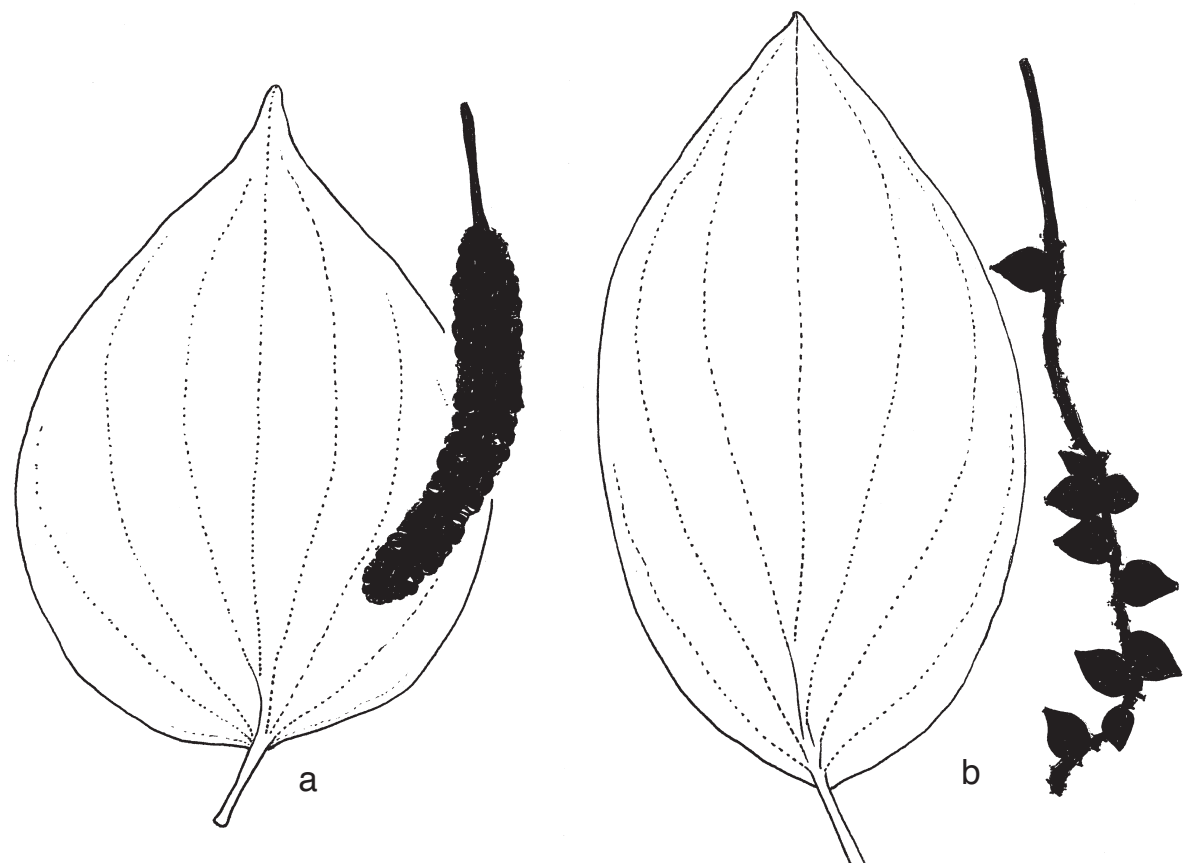

Fig. 3. Piper species. Fertile-shoot leaves $(\times 0.5)$ and infructescences (generalized $\times 1)$. - a. P. philippinum Miq.; after PPI 27123 (leaf only) and Quisumbing (1930), f. 59. - b. P. quinqueangulatum Miq.; after Quisumbing (1930), f. 94.

or villous and obviously multiseptate. In some cases the hairs may be minute (less than c. $0.2 \mathrm{~mm}$ long) and occur only on the basal part of the midrib and nerves and in the petiole channel (e.g., P. retrofractum). The vegetative parts of five species, P. baccatum, $P$. decumanum, $P$. interruptum, $P$. quinqueangulatum and P. philippinum, are perhaps always glabrous, while the leaves of $P$. abbreviatum rarely have a few hairs near the midrib base.

Minute red gland-dots, and larger white ones ("scales" sensu Huber, 1988: 283) are characteristic of the Piper leaf blade but they are not always conspicuous. The relatively thin-leaved species $P$. abbreviatum is consistently and copiously red-glandular, while the chartaceous-leaved $P$. interruptum usually shows both kinds of gland quite distinctly. Glands are hard to detect in the more coriaceous-leaved taxa, sometimes being obscured by the wrinkling and blistering that occurs in drying. Also, in P. retrofractum, the stomata may dry dark and then resemble gland-dots.

In P. celtidiforme both kinds of gland are inconspicuous. However, under low to moderate magnification the surface of the blade (particularly the upper) is seen to have red-brown areas, like narrow-armed pieces of jigsaw, slightly raised above the pale background (Fig. 4a). This mottling derives from dense coloration in the several layers of both the upper and lower hypodermis.

The degree to which the leaf base is symmetric or asymmetric is taxonomically useful. Blades of the latter kind may have their two sides ending at the petiole channel 

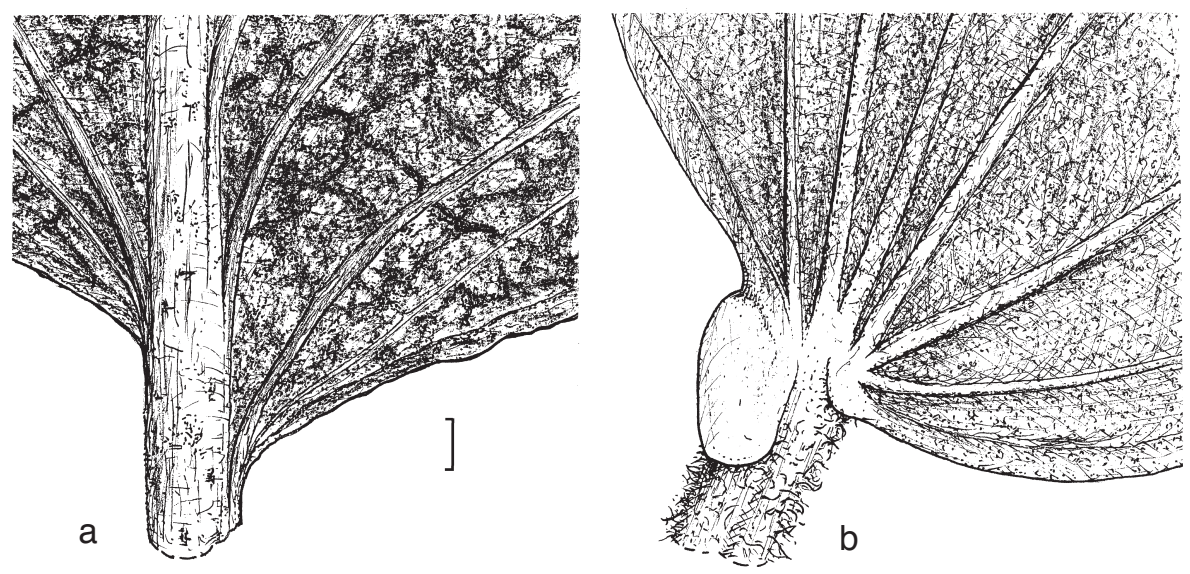

Fig. 4. Piper species. Leaf bases, generalized. - a. P. celtidiforme Opiz; abaxial surface; blade slightly oblique, conspicuously dark-mottled. - b. P. macropiper Opiz; adaxial surface; blade base with a unilateral lobule. Scale bar $=1 \mathrm{~mm}$.

one or two millimetres offset (e.g., as often seen in P. caninum and P. celtidiforme: Fig. $4 \mathrm{a})$, or the base itself may be expanded on one side more than the other ( $P$. decumanum especially, also $P$. lessertianum). In $P$. macropiper one side of the leaf base is shortly decurrent and expanded against the petiole apex as a 'lobule' c. 1-2 $\mathrm{mm}$ in diameter (Fig. 4b).

\section{Inflorescence and fruit}

Good diagnostic characters of the female inflorescence, in addition to overall size (Fig. 1-3), are found in the shape and size of the bracts and stigmas, and in the position of the ovary (free, or basally sunk into the rachis, or deeply sunk and 'concrescent' with the rachis and neighbouring ovaries). Mostly these characters are available at the fruiting stage too (except that the stigmas are fragile in P. celtidiforme). It is serendipitous then that because of the conspicuousness of the orange or red fruits it is mostly this useful stage that is collected. But the corollary is that male material is poorly represented in the herbarium. So although the grouping of the stamens, and anther size, position at anthesis, and mode of dehiscence are all useful features, they have generally been omitted from the key below.

The term 'fruitlet' has been used for the individual units of the compound Piper fruit. Quisumbing (1930) simply says "fruit", while other authors use "drupe" or bacca (berry).

The species are consistently dioecious, with the exceptions of $P$. betle, which (as cultivated) often has a bisexual inflorescence, and P. philippinum, which in the Philippines is said to have rudimentary ovaries in its male spikes (Quisumbing, 1930: 114). Perhaps bisexual spikes can be expected in other species as an anomaly, but observation of an artificial hybrid between the two amply distinct New Zealand species of Macropiper (ROG, unpubl. data) leads me to speculate that the production of bisexual spikes, with or without malformation of floral parts, might sometimes be a sign of hybridity. 


\section{SPOT CHARACTERS}

As typical of the species; brackets indicate a sporadic occurrence.

\section{Stem}

Strongly ridged to narrowly winged: quinqueangulatum

\section{Petiole}

Ant-sac at apex: myrmecophilum

More than 0.2 times as long as blade: (abbreviatum), fragile

\section{Leaf blade}

Peltate: (fragile)

More than $25 \mathrm{~cm}$ long: decumanum, (lessertianum), (majusculum)

Less than $3 \mathrm{~cm}$ wide: (abbreviatum), (caninum)

Drying glossy grey-ochre or -olive: retrofractum

Drying grey-yellow or -olive, surface blistered and rugose: caninum

Glabrous: abbreviatum, baccatum, decumanum, interruptum, philippinum, quinqueangulatum

Glabrous except for a few short patent hairs on petiole: (abbreviatum), (celtidiforme), retrofractum

Minutely pubescent (hairs that resemble cystoliths) near base below: betle

With abundant pale to dark long hairs: (macropiper), myrmecophilum

Base with a unilateral lobule to c. 2 mm long: macropiper

Reddish gland-dots copious and conspicuous above and below: abbreviatum, (interruptum), (lessertianum), quinqueangulatum

Reddish mottles on blade above and below: celtidiforme

\section{Male inflorescences}

Spike greater than $15 \mathrm{~cm}$ long: decumanum, (lessertianum), macropiper, majusculum, (philippinum), (quinqueangulatum)

Bracts sessile, elongate, 2-4 mm long, only free at tips and lateral margins: interruptum, quinqueangulatum

Bracts sessile, 1-1.3 mm diam.: caninum, retrofractum

Bracts forming a low \pm 2 -lipped cupule around a group of 5-8 stamens: baccatum

Stamens more than $1.5 \mathrm{~mm}$ long: interruptum

Stamens solitary, filament very swollen (c. $1 \mathrm{~mm}$ diam.): quinqueangulatum

Anthers dehiscing c. $1 \mathrm{~mm}$ above bracts: caninum, (celtidiforme), interruptum, quinqueangulatum

Anthers less than $0.35 \mathrm{~mm}$ diam.: baccatum, caninum

Anther locules lateral, c. $0.25 \mathrm{~mm}$ diam., connective swollen above: celtidiforme

Rudimentary ovaries consistently present: philippinum

\section{Female inflorescences}

Peduncle (0.5-)1-2 times as long as spike: abbreviatum, fragile Spike more than $20 \mathrm{~cm}$ long: decumanum, (macropiper), majusculum Spike more than $1.3 \mathrm{~cm}$ diam.: myrmecophilum 
Bracts sessile, elongate, 2-4 mm long, free only at tips and lateral margins: interruptum

Bracts forming a \pm 2 -lipped cupule around ovary: baccatum

Bract-heads thickened-rugose over central half: (betle), retrofractum

Styles $5 \mathrm{~mm}$ or more long: myrmecophilum

Stigmas not obviously (times 10) brown-papillose: celtidiforme

Stigmas linear-lanceolate, 3 , together c. $1 \mathrm{~mm}$ diam.: celtidiforme

Stigmas lanceolate, (3-)4-7, together 1-1.5 mm diam.: betle

\section{Infructescence}

Fruitlets half to fully concrescent with rachis: abbreviatum, betle, fragile, majusculum, retrofractum

Fruitlets slightly sunk into rachis and concrescent with it: philippinum

Fruitlets distant: baccatum, caninum, interruptum, quinqueangulatum

Fruitlets long-stipitate: caninum

Fruitlets more than $3.5 \mathrm{~mm}$ diam.: baccatum, (caninum), quinqueangulatum

\section{KEY TO THE CLIMBING SPECIES}

1a. Leaf blades large (often more than $18 \mathrm{~cm}$ long) and usually subcoriaceous. Minor veins regularly prominent on both surfaces $\ldots \ldots \ldots \ldots \ldots \ldots \ldots \ldots \ldots \ldots$

b. Leaf blades usually less than $18 \mathrm{~cm}$ long, membranous to chartaceous-subcoriaceous. Minor veins only weakly and irregularly prominent above . . . . . . 5 5

2a. Base of blade with a unilateral lobule c. 1-2 mm diameter. Blade glabrous to softly bristly or villous. Venation palmate, the 2 (or 3 ) pairs of nerves all arising $0-5(-10)$ $\mathrm{mm}$ above the blade base $\ldots \ldots \ldots \ldots \ldots \ldots \ldots \ldots$ 10. P. macropiper

b. Base of blade without a unilateral lobule . . . . . . . . . . . . . 3

3a. Long dark bristly hairs to c. $3 \mathrm{~mm}$ long on vegetative and fertile parts. Apex of petiole on underside developed into a bristly rugose ant-sac c. $1 \mathrm{~cm}$ diam. (sometimes absent?). Female spikes to $5.5 \mathrm{~cm}$ long, $1.5-2.5 \mathrm{~cm}$ diameter. Bracts and styles notably elongate (to c. $6 \mathrm{~mm}$ long). Leaves c. $20 \times 7 \mathrm{~cm}$, drying glossy dark brown $\ldots \ldots \ldots \ldots \ldots \ldots \ldots \ldots \ldots \ldots \ldots \ldots \ldots \ldots \ldots$ 12. P. myrmecophilum

b. Hairs if present less than c. $0.5 \mathrm{~mm}$ long. Apex of petiole never with an ant-sac. Female spikes more than $25 \mathrm{~cm}$ long but not exceeding $1 \mathrm{~cm}$ diam. even in fruit

4a. Glabrous over all vegetative parts. Blades usually drying pale yellowish brown, c. $30 \times 13 \mathrm{~cm}$, very unequally cordate-auriculate at base. Venation palmatepinnate, with 4-7 pairs of nerves, the lowermost 3-5 pairs arising from midrib base. Fruitlets free but crowded, 1-1.5 mm diameter. Stigmas 2 (or 3), about as wide as long, borne on a tapering style c. $1 \mathrm{~mm}$ long ........ 6. P. decumanum

b. Short pale hairs usually copious on midrib and nerves below. Blade usually drying leaden olive, c. $22 \times 12 \mathrm{~cm}$, at base only somewhat cordate-auriculate and usually only weakly unequal. Venation \pm pinnate, with c. 6 pairs of lateral nerves. Fruitlets concrescent, 1-1.5 mm diameter. Stigmas 3 or 4, broadly ellipsoid, sessile .... 
5a. Base of blade with a small unilateral lobule. Venation palmate, of 2 or 3 pairs of basal nerves, these and the lesser venation low-prominent above. Inflorescences often more than $12 \mathrm{~cm}$ long. Fruitlets crowded but free, c. $1 \mathrm{~mm}$ diam., the stigmas 3 , broadly ellipsoid, sessile

10. P. macropiper

b. Base of blade without a unilateral lobule. Venation palmate to subpinnate, at least the finer venation above coplanar or hardly prominent and only irregularly so. Fruitlets free or concrescent with one another or rachis $\ldots \ldots \ldots \ldots \ldots$

6a. Peduncle of female inflorescence usually almost as long or longer than spike. Fruiting spike oblong-subglobose, $(0.5-) 1-2 \mathrm{~cm}$ long. Fruitlets almost fully coalescent. Leaf blades glabrous (rarely $P$. abbreviatum with minute hairs near midrib base)

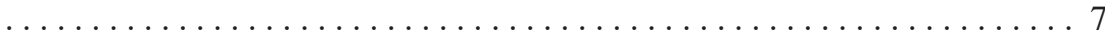

b. Peduncle of female inflorescence much shorter than spike. Fruiting spike cylindrical and (1-) $2 \mathrm{~cm}$ or more long. Fruitlets concrescent or not. Leaf blades glabrous

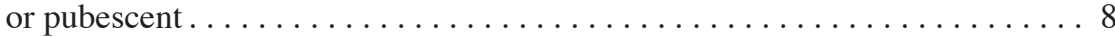

7a. Leaf blades ovate, c. $8 \times 4 \mathrm{~cm}$, membranous to chartaceous, usually drying dark, usually copiously and conspicuously dotted with red glands on both surfaces, cuneate(-rounded) at base, acuminate at apex. Fruitlets c. 1.5-2 mm diam., glandular-tuberculate over their rounded apex .......... 1. P. abbreviatum

b. Leaf blades broad-ovate, c. $6 \times 4.5 \mathrm{~cm}$, usually firmly chartaceous, usually drying yellowish ochraceous and the gland-dots not conspicuous, rounded at base, acute or shortly acuminate at apex. Fruitlets c. $2-3 \mathrm{~mm}$ diam., usually not prominently gland-dotted over apex. . . . . . . . fragile

8a. Fruitlets 3-6 mm diam., \pm distantly spaced along a rachis usually more than $7 \mathrm{~cm}$ long. Bracts of female (and male) spikes sessile . . . . . . . . . . 9

b. Fruitlets 1-3 mm diam., crowded, free or concrescent, on a rachis (1.5-)2-6 $\mathrm{cm}$ long. Bracts of female spikes either stalked (P. celtidiforme, P. lessertianum,

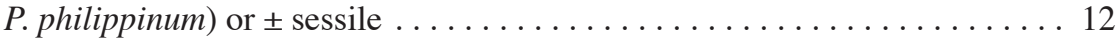

9a. Vegetative parts with rather slender \pm patent hairs c. $0.5 \mathrm{~mm}$ long (rarely lacking from all except petiole channel). Bracts of female spike \pm orbicular, $0.8-1.3 \mathrm{~mm}$ diameter. Fruitlets c. 3-4 mm diam., distinctly stalked (stalk 1-4 mm long). Leaf blades usually drying pale olive, ovate, c. $9 \times 5 \mathrm{~cm}$ (occasionally only $1-2 \mathrm{~cm}$ wide), slightly unequally cuneate to shortly cordate at base . . . 4. P. caninum

b. Vegetative parts glabrous. Fruitlets not stalked (except sometimes in P. baccatum).

Leaf blades usually drying dark or brown, \pm equally rounded at base . . . . 10

10a. Fruitlets $2-3 \mathrm{~mm}$ diam., subglobose to ellipsoid. Leaf blades chartaceous, seldom more than $10 \times 4 \mathrm{~cm}$, drying greyish and usually with conspicuous white glands. Venation palmate. Bracts of male and female spikes sessile, elongate along rachis and adnate to it except marginally. Stamens 2 or 3 , at dehiscence the anthers exserted by c. $1 \mathrm{~mm} \ldots \ldots \ldots \ldots \ldots \ldots \ldots \ldots$ 8. P. interruptum

b. Fruitlets 3-6 mm diam., subglobose or ovoid. Leaf blades subcoriaceous, often more than $10 \times 5 \mathrm{~cm}$, tending to dry dark brown (reddish) and with white glands not conspicuous (but red glands often so in P. quinqueangulatum). Venation subpalmate to subpinnate. Anthers exserted or not . . . . . . . . . . 11

11a. Stem terete. Bracts of male and female spikes forming a low cupule around fertile parts. Fruitlets subglobose, usually strongly wrinkled. Male spikes to c. $6 \mathrm{~cm}$ long. Stamens 5, anthers not exserted ............. P. baccatum 
b. Stem angled to narrowly winged. Bracts of male and female spikes sessile, elongated along rachis and adnate to it except marginally. Fruitlets \pm ovoid and strongly beaked, sometimes strongly longitudinally ridged. Stamens solitary, the anther exserted on a greatly swollen filament . . . . 14. P. quinqueangulatum

12a. Fruitlets crowded but free, less than $2.5 \mathrm{~mm}$ diameter. Leaf blades drying reddish brown to ochre or olive, chartaceous or ( $P$. philippinum) subcoriaceous, hairy or

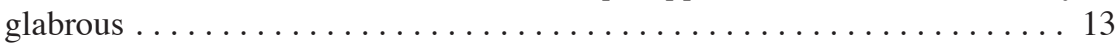

b. Fruitlets strongly concrescent with one other and rachis, c. 3-4 mm diameter. Leaf blades drying silvery greyish olive (particularly $P$. retrofractum) to greyish brown, firmly chartaceous to subcoriaceous, glabrous except sometimes for a few

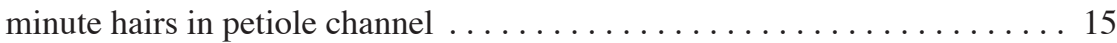

13a. Leaf blades chartaceous to subcoriaceous, broadly ovate, glabrous, red glands sometimes conspicuous. Stigmas usually persisting, 3, broadly triangular, together c. $0.8 \mathrm{~mm}$ diameter. Fruitlets crowded, free but their bases sunk into rachis and coalescent with it, subglobose, c. 2-2.5 mm diameter. Male spikes c. $2.5 \mathrm{~mm}$

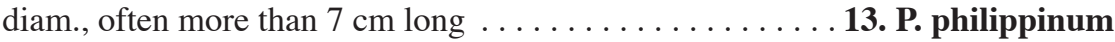

b. Leaf blades chartaceous, ovate-oblong, glabrous or not. Fruitlets \pm oblong, c. 1-1.5 $\mathrm{mm}$ diameter. Stigmas fragile or persistent. Male spikes 3-5 mm diam., seldom

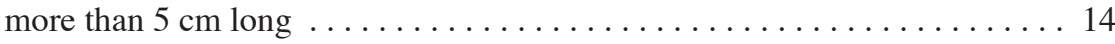

14a. Leaves glabrous. Blades c. $15 \times 8 \mathrm{~cm}$, red and white glands present but not conspicuous, and especially the upper surface with red mottling (times 20), weakly unequally truncate to shortly rounded at base. Stigmas 3-5 on a short style, linearlanceolate, together c. $1 \mathrm{~mm}$ diam., fragile. Fruitlets \pm broadly ellipsoid, c. 1-1.5 mm diameter . . . . . . celtidiforme

b. Leaves usually with patent to crisped or appressed hairs on venation of blade and on petiole. Blades c. $12 \times 5 \mathrm{~cm}$, often copiously dotted with red-orange glands on both surfaces, red mottling absent. Stigmas 3, sessile, ovate, together c. $0.5 \mathrm{~mm}$ diam., usually persistent. Fruitlets \pm broadly ellipsoid, c. 1-1.5 mm diameter. . .

9. P. lessertianum

15a. Spikes usually bisexual, in fruit the low-emergent tops of the fruitlets ringed by a rachis-derived annulus of appressed villous brown hairs. Petiole c. 0.15 times as long as blade. Blades usually drying greyish brown and relatively chartaceous, ovate, c. $15 \times 8 \mathrm{~cm}$, often with sparse pale minute hairs $(0.03 \mathrm{~mm}$ long) below especially near base. Stigmas sessile, narrow-ovate, (3-)4-7, together 1-1.5 mm diameter . . . . . . . . . betle

b. Spikes unisexual. Rachis of female spikes glabrous. Petiole c. 0.1 times as long as blade. Blades usually drying silvery grey-olive and firmly chartaceous to subcoriaceous, ovate-elliptic or -oblong, c. $15 \times 8 \mathrm{~cm}$, glabrous. Stigmas sessile, ovate, 3 or 4 , together $0.5-1 \mathrm{~mm}$ diameter

15. $P$. retrofractum 


\section{THE CLIMBING SPECIES}

The habitat and altitudinal range data here apply only to the Philippine Islands occurrences of these species.

\section{Piper abbreviatum Opiz - Fig. 1a}

Piper abbreviatum Opiz (1828) 157; Quisumb. (1930) 58, pl. 20; Chew (1972) 1; (2003) 14. - Type:

Haenke s.n. (holo PR n.v.), Luzon.

Distribution - Philippines to Solomon Islands and Australia.

Habitat - Most of the specimens I have seen come from forests at 200-1000 m altitude.

Note - The record here for Australia is based on material in MEL (e.g., Foreman 1694, Mt Lewis road).

\section{Piper baccatum Blume - Fig. 1b}

Piper baccatum Blume (1826) 172; Quisumb. (1930) 175. - Type: Zollinger 1525 (L, G n.v.), Java.

Distribution - Malesia (Philippines, Borneo, Java).

Habitat - Quisumbing (1930) gave no altitude data for this forest species.

Note - Quisumbing (1930) cited 3 collections under P. baccatum, all from Mindanao. He also cited 4 collections from Luzon as $P$. sarcopodum C.DC., supposedly distinguished by the cupules of its female spike being stalked. Material from Java has this feature too (Backer \& Bakhuizen van den Brink, 1963). I do not think the distinction is significant.

\section{Piper betle L. - Fig. 1c}

Piper betle L. (1753) 28. - Type: Herb. Hermann 3:32, 4:9 (BM n.v.).

Distribution - Widely cultivated in Asia and through Malesia to the Solomon Islands and Fiji.

Habitat - Gardens, old clearings and secondary forest, at low and medium altitudes to c. $1400 \mathrm{~m}$.

Notes - Specimens I have seen with adequate label data come mostly from secondary or disturbed lower-altitude forests. Perhaps some are garden relics or have naturalized from gardens.

In the western part of its range this anciently cultivated plant, the betel pepper, is grown primarily for the carminative and breath-freshening actions of its leaf (Burkill, 1966). Further east it is generally the fruit spike that is used, to chew with the Areca catechu palm nut. Quisumbing (1930) described his Philippines material as dioecious, but some of the material I have seen has bisexual spikes. What Burkill (1966: 1779) said about $P$. nigrum can be presumed to apply also to $P$. betle: "exclusively male plants are found, but who is likely to take cuttings from a plant which bears no fruit ?". That is, there probably has been artificial selection in the betel-chewing region for bisexual (and self-fertile) spikes. In this respect, the unusually large and numerous coronate stigmas of $P$. betle might indicate selection for a larger spike too. 
4. Piper caninum Blume - Fig. 1d, e

Piper caninum Blume (1826) 214; Quisumb. (1930) 120; Chew (1972) 5. - Type: Blume s.n. (L n.v.), Java.

Distribution - Western Malesia to the Solomon Islands and Australia.

Habitat - Most of the specimens I have seen come from forests at c. $200-800 \mathrm{~m}$ altitude.

Note - Small-leaved specimens were placed by Quisumbing (1930) mostly in $P$. viminale Opiz, while those with larger leaves were placed under one or other of more than a dozen names, chiefly P. haenkeanum Opiz; the illustrations and key characters given, however, suggest all the names are synonyms of $P$. caninum.

\section{Piper celtidiforme Opiz - Fig. 1i, 4a, 5}

Piper celtidiforme Opiz (1828) 152; Quisumb. (1930) 177, pl. 22. - Type: Haenke s.n. (holo PR n.v.), Luzon.

Piper obesispicum S. Moore (1923) 40, syn. nov. - Type: Forbes 35 (holo BM n.v.; iso MEL 578201 !), 1885-1886, New Guinea, Sogeri Plateau ('Sogere'), 2500 feet.

Piper fosbergii ('fosbergi’) Trel. (1940) 111, pl. 1, syn. nov. - Type: Stewart s.n. (holo BISH 573050 !), Solomon Islands, Guadalcanal, Kau Kau Bay, 22 May 1933.
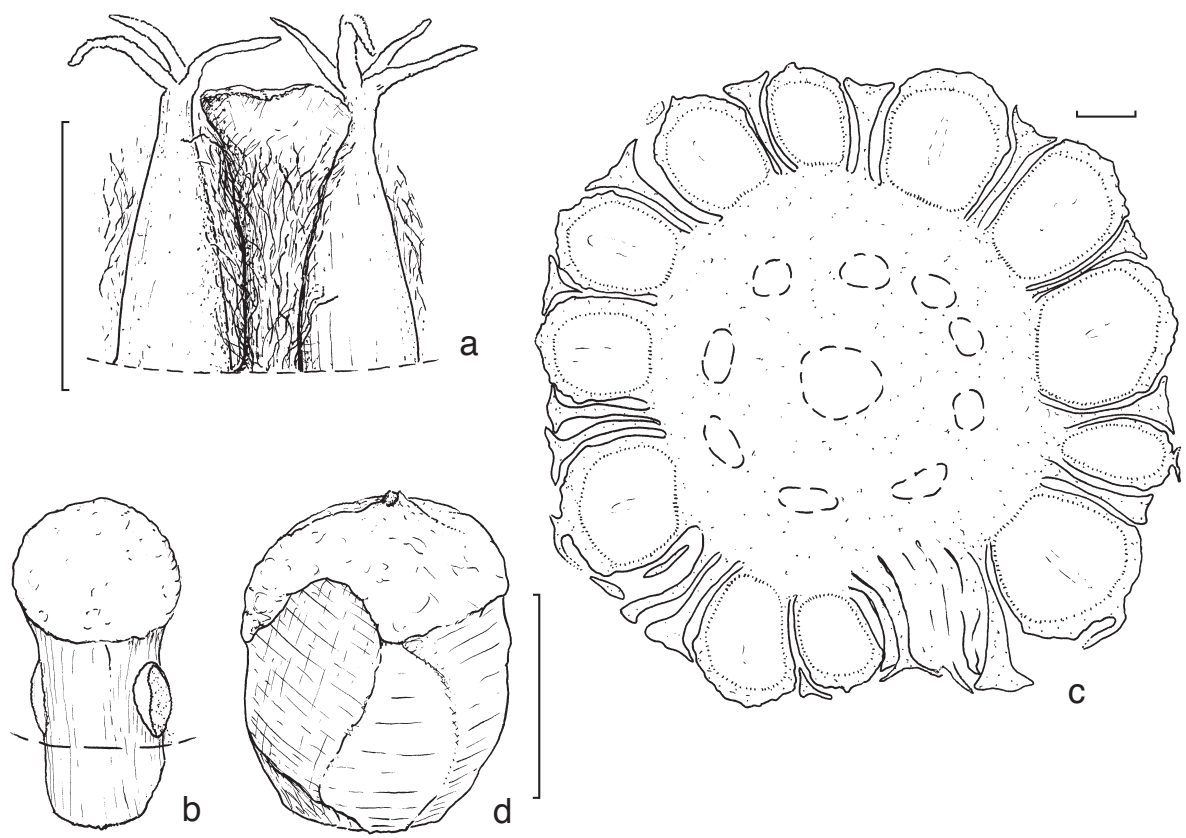

Fig. 5. Piper celtidiforme Opiz. - a. Two female flowers and hairy bract. Dashed line is surface of rachis. Scale bar $=1 \mathrm{~mm}$. Gardner 9068 (AK), New Guinea; b. stamen with swollen connective head and pair of lateral anther-locules; dashed line is level of bract-heads. Scale bar as in a. Gardner 8922 (AK), New Guinea; c. TS of fruiting spike. Fruitlets are crowded but free. Dashed circles in rachis are mucilage channels. Scale bar $=1 \mathrm{~mm}$. PPI 7730 (BRIT); d. solitary fruitlet. Upper part fleshy, lower part \pm hexagonally-compressed. Stigmas lost. Scale bar $=1 \mathrm{~mm}$. PPI 7730 (BRIT). 
Distribution - Philippines, New Guinea, Solomon Islands.

Habitat - Quisumbing (1930) said that this taxon (as circumscribed here also to include material he described under $P$. catubigense Merr., $P$. penninerve C.DC. and P. villirache C.DC.) was found at low and medium altitudes, to $1300 \mathrm{~m}$. The twelve specimens that I have seen with altitude data range from 250 to $800 \mathrm{~m}$.

Notes - In his published studies of Piper in eastern Malesia Chew deliberately made no mention of $P$. celtidiforme, wanting to examine a sufficiency of Philippines specimens (pers. comm. to ROG, 2004). Having done so myself, and having seen the CANB specimens Chew has annotated and also the types of the two new synonyms, I am sure the plants of these areas are conspecific. The stout (always \pm erect?) male spikes with their uniquely swollen-headed stamens, and the stout female spikes with their fragile lanceolate stigmas, are very distinctive.

The description of the stigmas in the protologue of $P$. obesispicum as " 2 minutis" is probably due to specimen breakage, the flowers of MEL 578201 having the usual several lanceolate stigmas.

Quisumbing (1930) emphasized for P. celtidiforme s.s. the deep lobing of the bractheads of the female spike, which would be an unusual character in the genus. His descriptions of $P$. catubigense etc. do not mention this character, and consistently deep lobing does not occur in the material I have seen from the Philippines or eastwards. Expansion of the ovary as it ripens into fruit will cause lobing of the bract-heads, particularly where the flowers are packed densely on a spike.

\section{Piper decumanum L. - Fig. $2 \mathrm{a}$}

Piper decumanum L. (1754) 19; Quisumb. (1930) 42; Chew (1972) 6. - Type: Rumph., Herb. Amb. 5 (1747) 45, t. 27.

Distribution - Philippines, Celebes, Moluccas, New Guinea.

Habitat - According to Quisumbing (1930) this robust climber is found in forests at medium altitude.

\section{Piper fragile Benth. - Fig. 1f}

Piper fragile Benth. (1843) 234; Quisumb. (1930) 99; Chew (1972) 7. - Type: Hinds s.n. (K n.v.), New Guinea.

Distribution - Philippines, Moluccas, New Guinea, Solomon Islands, Micronesia.

Habitat - This is usually a coastal species. Quisumbing (1930) described it as found "on rocks near the sea, in thickets and forests at low and medium altitudes".

\section{Piper interruptum Opiz - Fig. 1h}

Piper interruptum Opiz (1828) 157; Quisumb. (1930) 154, pl. 21. - Type: Haenke s.n. (holo PR n.v), Luzon.

Distribution - Taiwan (?), Philippines and probably elsewhere in western Malesia, New Guinea, Solomon Islands, Vanuatu, Australia. 
Habitat - In forest at low and medium altitudes (Quisumbing, 1930). The specimens I have seen are mostly from 400-1200 m altitude, the highest being from $2600 \mathrm{~m}$.

Notes - The record here for Vanuatu is based on MEL 1523097, its collector unknown.

Quisumbing (1930) stated that P. nigrum L. (black pepper, white pepper) was grown to a limited extent in the Philippines. From his description and those of others (Backer \& Bakhuizen van den Brink, 1963; Burkill, 1966; Huber, 1988) it appears that $P$. nigrum regularly has: bisexual spikes, globose sessile fruits, and bracts that tend to be circular. Leaf venation, the greyish colour when dry, the abundance of white (and sometimes red) glands, and the inflorescence structure, give these two species a close resemblance. In the Philippines, however, $P$. interruptum has less coriaceous leaves with a more nearly palmate venation.

\section{Piper lessertianum (Miq.) C.DC. - Fig. $1 \mathrm{j}$}

Piper lessertianum (Miq.) C.DC (1866) 164; Quisumb. (1930) 36; Chew (2003) 17. - Chavica lessertiana Miq. (1843) 270. - Type: Cuming 1343 ('1342’) (holo BM n.v.), Luzon.

Distribution - Philippines, Celebes, New Guinea.

Habitat - In damp forests at medium altitudes (Quisumbing, 1930). Most of the specimens I have seen come from c. 400-2200 m altitude, with one from $2800 \mathrm{~m}$.

Note - Typification is discussed by Chew (2003).

\section{Piper macropiper Pennant - Fig. 1g, 4b}

Piper macropiper Pennant (1800) 242; Merr. (1948) 191; Chew (1972) 10. - Type: Rumphius, Herb. Amb. 5 (1747) 46, t. 28, f. 1.

Piper arborescens Roxb. (1814) 80; Quisumb. (1930) 20. - Type: Rumphius, Herb. Amb. 5 (1747) 46 , t. 28 , f. 1.

Distribution - Taiwan, Philippines and Malay Peninsula south-east to Solomon Islands and Australia.

Habitat - Quisumbing (1930) said this species was "common in forests at low and medium altitudes, ascending to 1300 metres". All the data-bearing specimens I have seen come from between 200 and $800 \mathrm{~m}$ altitude.

Note - This species is characterized by its firm, palmately nerved, usually narrowly ovate leaf blade, which always has a small unilateral basal lobule (auricle); glabrous and hairy-leaved forms are about equally frequent. The long male and female spikes (each often more than $15 \mathrm{~cm}$ long) and the free but close-packed small fruitlets (c. 0.75 $\mathrm{mm}$ diam.) are also distinctive.

\section{Piper majusculum Blume - Fig. $2 b$}

Piper majusculum Blume (1826) 210; Quisumb. (1930) 45; Chew (1972) 12. - Type: Blume s.n. (L n.v.), Java, Mt Salak.

Distribution - Indonesia, Philippines, New Guinea, Solomon Islands.

Habitat - Quisumbing (1930) described this species as growing "in forests at low and medium altitudes". 


\section{Piper myrmecophilum C.DC. - Fig. 2c}

Piper myrmecophilum C.DC. (1916) 211; Quisumb. (1930) 56. - Type: Ramos, B.S. 17599 (iso L n.v.) Samar, Mt Cauayan.

Distribution - Endemic to the Philippines.

Note - Quisumbing (1930) cited 6 collections, from Samar and Leyte, "in damp forests at low and medium altitudes". The three data-bearing collections I have seen come from 50, 100 and $400 \mathrm{~m}$ altitude.

\section{Piper philippinum Miq. - Fig. 3a}

Piper philippinum Miq. (1843) 322; Quisumb. (1930) 110. - Type: Cuming 1642 (holo G or P? n.v.), in insulis Philippinis [Luzon?].

Distribution - Southern China, Taiwan, Philippines.

Habitat - In thickets and forest at low and medium altitudes, to $1550 \mathrm{~m}$ (Quisumbing, 1930).

Notes - The slender male spikes, which may reach $17.5 \mathrm{~cm}$ long (Quisumbing, 1930: 115), the robust stigmas, and the crowded globular fruitlets with their bases embedded in the rachis give $P$. philippinum a considerable likeness to $P$. austrocaledonicum C.DC. The type of this is from New Caledonia, but Chew (2003: 17) lists specimens from New Guinea as well and also hints that P. elbertii C.DC. of the Sunda Islands might be conspecific.

Quisumbing (1930) examined numerous Philippines specimens of P. philippinum (which I consider includes $P$. albidirameum C.DC. and P. magnasanum C.DC.). He found that the male spikes have rudimentary ovaries, which remain sterile; also, that some spikes have the stamens more abundant than the ovaries, while in others the reverse is true. I have not seen any male material.

\section{Piper quinqueangulatum Miq. - Fig. 3b}

Piper quinqueangulatum Miq. (1854) 85. - Type: Zollinger 1233 (L? n.v.), Java. Piper korthalsii Miq. (1863) 139; Quisumb. (1930) 169. - Type: Korthals, W Sumatra (L? n.v.).

Distribution - Philippines, Sumatra, Java and perhaps westwards.

Habitat - In damp forests at medium altitudes (Quisumbing, 1930). Most of the specimens I have seen come from c. 400-2200 m altitude, with one from $2800 \mathrm{~m}$.

Notes - The ridged stems, large beaked fruitlets, and especially the solitary, swollenbased stamens, are all characteristic, but in their bracts and stigmas immature female inflorescences are much like those of $P$. interruptum.

Outside the Philippines, P. bosnicanum of New Guinea and the Solomon Islands is of this affinity, in foliage and female inflorescence characters, and in the solitary stamen too.

\section{Piper retrofractum Vahl - Fig. $2 \mathrm{~d}$}

Piper retrofractum Vahl (1804) 314; Quisumb. (1930) 106. - Type: Unknown collector (Herb. Vahl, $\mathrm{C}$ microfiche!), habitat in India orientali.

Distribution - Southeast Asia to the Moluccas. 
Habitat - Quisumbing (1930) said this species grew "in thickets at low altitudes". The data-bearing specimens I have seen come from near sea-level to $850 \mathrm{~m}$ altitude.

\section{THE SHRUBBY SPECIES}

\section{Piper aduncum L.}

Robust shrub or treelet to $4 \mathrm{~m}$ or more tall. Leaf blades ovate, c. $15 \times 5 \mathrm{~cm}$, firmly chartaceous, pinnate-veined with 4-8 pairs of lateral nerves, finely scabrid above with short pale curved hairs to c. $0.5 \mathrm{~mm}$ long; petiole mostly less than $1 \mathrm{~cm}$ long, c. 0.05 times length of blade. Fruitlets small, crowded but free. Adventive to the Philippines. Not treated by Quisumbing (1930), but in L there is a collection made near Manila by M. Clemens in 1929 (A. Hardemink, pers. comm.). Specimens I have seen are PPI $4351,5221,5750,8976,13101$; the three with altitude data come from c. $800 \mathrm{~m}$.

\section{Piper begoniaefolium (Blume) Quisumb.}

Subshrub to c. $50 \mathrm{~cm}$ tall, glabrous. Leaf blades ovate, c. $10 \times 5 \mathrm{~cm}$, membranous, palmate veined with 2 pairs of nerves, cordate at base; petiole $1.5-3 \mathrm{~cm}$ long. Inflorescence leaf-opposed, erect, c. 10-15 cm long, bisexual; fruitlets distant, glochidiate. Perhaps mostly at middle altitudes. - Zippelia begoniaefolia Blume in Roemer \& Schultes (1830).

\section{Piper sarmentosum Roxb.}

Stoloniferous shrub or low scrambler, to c. $1 \mathrm{~m}$ tall. Leaf blades ovate, c. $10 \times 4 \mathrm{~cm}$, membranous, \pm palmate-veined with 2 or 3 pairs of lateral nerves, puberulent below; petiole c. $0.5-1.5 \mathrm{~cm}$ long. Inflorescences leaf-opposed, unisexual, the female spike c. 1-2 cm long, fruitlets shortly embedded in rachis, c. $2 \mathrm{~mm}$ diameter. At low altitudes.

Piper subbullatum K. Schum. \& Lauterb.

Robust shrub or treelet to $4 \mathrm{~m}$ or more tall. Leaf blades broadly ovate to suborbicular, c. $25 \times 20 \mathrm{~cm}, \pm$ chartaceous, palmate-veined with 4 or 5 (or 6) pairs of lateral nerves, the innermost pair usually fused with midrib for up to c. $2 \mathrm{~cm}$, glabrous above, below with a few minute hairs mostly on veins, margins usually densely short-ciliate. Petiole to $15 \mathrm{~cm}$ long. Inflorescences leaf-opposed, unisexual. Fruitlets crowded, free, c. $1 \mathrm{~mm}$ diameter. - Piper lageniovarium C.DC. Native to the Philippines. At medium altitudes, according to Quisumbing (1930).

\section{Piper subpeltatum Willd.}

Soft-wooded shrub (usually few-stemmed) to 1(-2) m tall. Leaf blades suborbicular, deeply cordate at base (sometimes slightly peltate?), c. $20 \mathrm{~cm}$ diam., membranous, palmate-veined with c. 7 pairs of lateral nerves, the innermost pair fused to midrib for $1-3 \mathrm{~cm}$; minute soft hairs on venation and margin; petiole $10-15 \mathrm{~cm}$ long. Inflorescence 
axillary, a subumbellate group of bisexual spikes; fruitlets crowded, free, c. $0.5 \mathrm{~mm}$ diameter. Adventive to the Philippines; the oldest collection cited by Quisumbing (1930) being Cuming 441, from Luzon, collected in the 1830s.

\section{ACKNOWLEDGEMENTS}

I am grateful to have received loans from the above-cited herbaria, and essential information from W.-L. Chew, A. Hardemink and G. Thijsse. At AK, Ewen Cameron and Mei Nee Lee provided curatorial support, as did Catherine Gallagher at MEL. Juliet Wege, Australian Botanical Liaison Officer at $\mathrm{K}$, helped with literature searches.

\section{REFERENCES}

Backer, C.A. \& R.C. Bakhuizen van den Brink. 1963. Flora of Java. Vol. I. Groningen.

Bentham, G. 1843. Enumeration of the plants collected by R.B. Hinds, Esq., and by Mr Barclay in the Feejee Islands, Tanna, New Ireland and New Guinea; to which are added a few species gathered in Amboina by Mr Barclay. London J. Bot. 2: 211-240.

Blume, C. 1826. Monographie der Oost-Indische Pepersoorten. Verh. Batav. Genootsch. Kunsten 11: $139-245$.

Burkill, I.H. 1966. A dictionary of the economic products of the Malay Peninsula. Ministry of Agriculture and Co-operatives. Kuala Lumpur.

Chew, W.-L. 1972. The genus Piper (Piperaceae) in New Guinea, Solomon Islands and Australia. 1. J. Arnold Arbor. 53: 1-25.

Chew, W.-L. 1992. Studies in Malesian Piperaceae II. Blumea 37: 159-164.

Chew, W.-L. 2003. Studies in Malesian Piperaceae 3. Gard. Bull. Singapore 55: 13-25.

De Candolle, C. 1866. Piperaceae Novae. Seemann's Journal of Botany 4: 161-167.

De Candolle, C. 1905. Piperaceae. In: J.R. Perkins, Fragmenta florae Philippinae, 153-160. Gebrüder Borntraeger, Leipzig.

De Candolle, C. 1910. A revision of Philippine Piperaceae. Philipp. J. Sci., Bot. 5: 405-463.

De Candolle, C. 1923. Piperacearum clavis analytica. Candollea 1: 65-415.

Gardner, R.O. 2003. Piper (Piperaceae) in New Guinea: the non-climbing species. Blumea 48: 47-68.

Huber, H. 1988 ('1987'). Piperaceae. In: M.D. Dassanake \& F.R. Fosberg (eds.), Flora of Ceylon. Vol. 6: 272-300. Amerind Publishing, New Delhi.

Linnaeus, C. 1753. Species plantarum. Stockholm.

Linnaeus, C. 1754. Herbarium amboinense, ... Olavus Stickman, Uppsala.

Merrill, E.D. 1923. An enumeration of Philippine flowering plants. Vol. 2.

Merrill, E.D. 1948. An overlooked Flora Indica. J. Arnold Arbor. 29: 186-192.

Miquel, F. A.W. 1843. Systema Piperacearum IV. Rotterdam.

Miquel, F. A.W. 1854. Piperaceae. In: H. Zollinger, Systematisches Verzeichniss: 83-86. Kiesling, Zürich.

Miquel, F.A.W. 1863. Piperaceae. Annales musei botanici Lugduno-Batavi 1, VIII, 134-141.

Moore, S. 1923. Piperaceae. In: A.B. Rendle, Dr H.O. Forbes's New Guinea plants. J. Bot., Suppl.: $40-41$.

Opiz, P.M. 1828. Piperaceae. In: C. Presl, Reliquae Haenkeanae: 150-164. Prague.

Pennant, T. 1800. Outlines of the Globe. Vol. 4. London.

Quisumbing, E. 1930. Philippine Piperaceae. Philipp. J. Sci. 43: 1-246, pl. 1-24.

Roemer, J.J. \& J.A. Schultes. 1830. Systema Vegetabilum. Vol. 7. Stuttgart.

Roxburgh, W. 1814. Hortus Benghalensis. Serampore.

Rumpf, G.E. 1747. Herbarium Amboinense. Vol. 5. Amsterdam/Den Haag.

Trelease, W. 1940. Piper. In: F.R. Fosberg, Melanesian vascular plants. Lloydia 3: 111-112.

Vahl, M. 1804. Enumeratio plantarum. Vol. 1. Copenhagen. 


\section{LIST OF COLLECTIONS}

Only Philippines collections of climbing Piper species are included. Nearly all belong to the PPI (Philippines Plants Inventory) series.

Incertae sedis: PPI 3390, 3820, 9169, 14040, 14542, 20284.

$$
\begin{aligned}
\text { abb } & =P . \text { abbreviatum } \\
\text { bet } & =P . \text { betle } \\
\text { can } & =P . \text { caninum } \\
\text { cel } & =P . \text { celtidiforme } \\
\text { dec } & =P . \text { decumanum } \\
\text { fra } & =P . \text { fragile } \\
\text { int } & =P . \text { interruptum }
\end{aligned}
$$

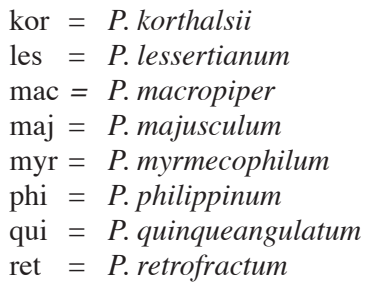

Maliwang 223: cel; 304: can; 327: cel.

PPI 298: can; 472: les; 854: ret; 962: qui; 966: les; 1013: abb; 1043: mac; 1135: abb; 1137: abb; 1158: can; 1182: abb; 1206: bet; 1311: abb; 1421: les; 1526: mac; 3246: les; 3431: dec; 4281: abb; 4669: les; 4813: maj; 4897: bet; 4938: qui; 4941: qui; 4993: les; 5023: mac; 5029: can; 5087: cel; 5125: cel; 5232: abb; 5260: qui; 5410: bet; 5436: abb; 5513: cel; 5561: abb; 5791: abb; 5900: abb; 6163: bet; 6183: can; 6210: les; 6212: les; 6298: can; 6376: int; 6699: phi; 7003: can; 7235: abb; 7277: bet; 7319: qui; 7350: les; 7513: cel; 7541: bet; 7730: cel; 7748: abb; 7823: abb; 7867: mac; 7879: abb; 7920: cel; 8036: mac; 8054: can; 8058: abb; 8065: mac; 8078: les; 8105: ret; 8250: les; 8257: les; 8308: cel; 8584: les; 8613: les; 8659: abb; 8919: ret; 9172: qui; 9363: myr; 9564: les; 9658: qui; 10000: ret; 10041: abb; 10042: ret; 10323: ret; 10350: int; 10404: abb; 10557: abb; 10884: bet; 11281: ret; 11284: ret; 11740: ret; 12050: myr; 12110: fra; 12251: les; 12268: abb; 12285: abb; 12315: can; 12812: les; 12923: can; 13062: mac; 13174: can; 13550: can; 14148: cel; 14465: can; 14494: les; 14535: les; 14540: les; 14543: les; 14813: cel; 14858: abb; 14946: cel; 15041: bet; 15255: can; 15413: abb; 15622: les; 15626: phi; 15747: can; 15813: qui; 15864: les; 15925: les; 16000: les; 16345: ret; 17056: cel; 17769: cel; 17775: cel; 17786: cel; 17910: bet; 17918: bet; 17966: bet; 18018: qui; 18078: mac; 18141: abb; 18209: can; 18281: can; 18360: can; 18373: abb; 18390: abb; 18421: cel; 18706: can; 20105: qui; 20136: les; 20350: cel; 21064: abb; 21074 : ret; 21197: can; 21234: cel; 21270: can; 21274: abb; 21305: cel; 21358: can; 21792: abb; 21923 : abb; 21927: mac; 22048: ret; 22374: bet; 22702: mac; 22710: ret; 22760: les; 22771: can; 22853: les; 22907: abb; 22995: int; 23094: can; 23149: abb; 23675: can; 24211: mac; 24225: myr; 24235 : les; 24470: ret; 24572: cel; 25090: int; 25122: int; 25175: les; 25205: ret; 25318: int; 26129: abb; 26172: cel; 26207: can; 26264: phi; 27052: cel; 27123: phi; 27447: cel; 29014: ret; 29267: cel; 29309: bet; 29534: int; 36105: ret; 37421: mac; 37540: ret; 37598: cel; 37694: qui; 37825: can; 37872: can; 38052: can; 38159: can; 38264: mac; 38436: can; 38679: mac; 38778: int.

Utzurrum 400: les. 